\title{
The influence of hydrothermal activity during the origin of Co-rich manganese crusts of the $\mathrm{N}$ - W Pacific
}

\author{
Pavel Mikhailik ${ }^{1, *}$, Alexandr Khanchuk $^{1}$, Evgenii Mikhailik ${ }^{1}$, Yuliya Ivanova ${ }^{1}$, and Maxim \\ Blokhin $^{1}$ \\ ${ }^{1}$ Far East Geological Institute FEB RAS, 690022, Vladivostok, 100-letiya Vladivostoka ave., 159, \\ Russia
}

\begin{abstract}
The distribution of cobalt, vanadium, cadmium and molybdenum in the mineral fractions of the Co-rich manganese crusts (CMC) from Zubov and Govorov Guyots is considered. It is shown that the concentrations of cobalt in the ferrous fraction, and vanadium, cadmium in the manganese fraction indicate the ability of the CMC to record the rejuvenated volcanism in the $\mathrm{N}-\mathrm{W}$ Pacific.
\end{abstract}

\section{Introduction}

The study of seamounts geological history is an important part in the knowledge of the oceanic lithosphere evolution. There are abounded the three genetic types of ferromanganese deposits (FMD) in the World Ocean which are studied in detail. These are hydrogenic cobalt-rich crusts from guyots; diagenetic ferromanganese nodules from abyssal basins; hydrothermal-sedimentary crusts formed in active geodynamic regions. The source for the first type is seawater, for the second type is from sediment pore fluid that consist of ocean water modified by chemical reactions within the sediment column, and for the last one is the hydrothermal fluid [1]. A detail study of FMD, in particular Co-rich manganese crusts (CMC, $\mathrm{Co}>2000 \mathrm{ppm}$ ), which growth on sediment free areas, showed their unique ability to record paleoenvironment features during formation [2].

There are volcanic cones and knolls are located on the flat-topped seamounts (guyots) in the N-W Pacific. The heights of such cones vary from 100 to $350 \mathrm{~m}$, knolls - from 50 to $200 \mathrm{~m}$, with maximum values of 550-650 $\mathrm{m}$ and 300-400 $\mathrm{m}$, respectively [3]. The number of superposed volcanic structures can reach several dozens and more than a hundred within a single guyot, and their age corresponds the rejuvenated stages volcanism in the Pacific [3].

It was shown that the CMC of guyots were formed during the Late Cretaceous [4], and the typical stratigraphic breaks of their formation correspond to volcanic activity in the Pacific. The volcanic cones and knolls on the guyots flat-top summits were dated as Late Paleocene - Eocene, Middle Miocene, and presumably Pliocene [3]. Thus, the formation of the $\mathrm{CMC}$ composition could be endogenic influenced, which can be reflected in element

*Corresponding author: mikhailik@fegi.ru 
distribution in mineral fractions [5]. We assume that the endogenic source during volcanic rejuvenated stages may make adjustments to the distribution of chemical elements between manganese and ferrous in-situ fractions. This paper is devoted to the study of this idea.

\section{Samples and methods}

FMD in the ocean consist of four mineral fractions (phases): I - loosely bound; II manganese (Mn oxide); III - ferrous (Fe oxyhydroxide); IV - residual [5, 6]. The ferromanganese crusts for the study were dredged from Govorov Guyot (Magellan Mountains) and Zubov Guyot (Marshall Islands) during geological cruise of $\mathrm{R} / \mathrm{V}$ "Gelendzhik" from October 2007 to April 2008. The mineral composition of CMC was indentified by X-ray powder diffractometer Rigaku Mini Flex II. ICP-AES, ICP-MS were used to determine the elements concentration. The study of chemical elements in CMC mineral phases was carried out by the method of sequential leaching (phase analysis) $[5,6]$. The procedure of analysis is detailed in [7].

\section{Results and discussion}

Ferromanganese deposits of Govorov and Zubov Guyots are represented by fragments of crusts without a substrate (Fig. 1). The structure of the crusts is represented by a typical section for the equatorial part of Pacific Guyots, in which three main layers are distinguished: "anthracite" (layer I, Paleocene-Eocene), "porous" (layer II, Miocene) and "brown-coal" (layer III, Pliocene-Quaternary). The oldest layer I was not studied in this research. The mineral composition of all layers is represented by vernadite, the main mineral that composes marine hydrogenic FMD. According to the concentration of manganese, iron and cobalt (table), as well as the mineral composition and conditions of geological occurrence, the studied FMD belong to the Co-rich manganese crusts.
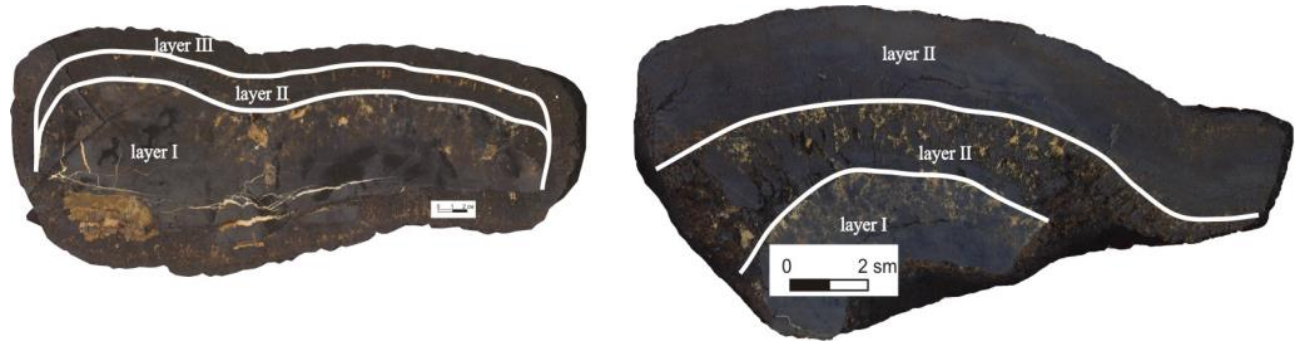

Fig. 1. Samples of ferromanganese crusts: $a$ - Zubov Guyot (33D17-1); $b$ - Govorov Guyot (08D51-1).

The ratio of cobalt, vanadium, cadmium and molybdenum in the manganese and ferrous fractions of the studied ferromanganese crusts are shown in Fig. 2.

The figure 2 demonstrate that the main cobalt concentrator in the hydrogenic crusts of the Central Pacific (5) is manganese oxides, while for the hydrothermal ferromanganese crusts of the North Fiji Basin (6) a large amount of cobalt found in the ferrous fraction.

In seawater $(\mathrm{pH} \sim 7.9)$, the oxide manganese phase $\left(\mathrm{pH}_{\mathrm{zpc}} 2.0-2.8\right.$; $\mathrm{zpc}$ is zero point charge) forms a high negative potential on the surface of hydrogenetic CMC and, hence, this phase should attract positively charged metal complex. Amorphous iron hydroxides $\left(\mathrm{pH}_{\mathrm{zpc}} 8.5\right)$ forming a weakly positive surface charge in seawater $(\mathrm{pH} \sim 7.9)$ would adsorb negatively charged particles [8]. 
Table. Concentration of $\mathrm{Mn}, \mathrm{Fe}$ and $\mathrm{Co}$ in ferromanganese crusts.

\begin{tabular}{|c|c|c|c|c|}
\hline \multirow{2}{*}{ Element } & \multicolumn{2}{|c|}{ Zubov Guyot } & \multicolumn{2}{c|}{ Govorov Guyot } \\
\cline { 2 - 5 } & layer II & layer III & layer II & layer III \\
\hline $\mathrm{Mn}(\%)$ & 22,9 & 25,9 & 28,4 & 25,5 \\
\hline $\mathrm{Fe}(\%)$ & 18,5 & 17,9 & 13,8 & 18,4 \\
\hline $\mathrm{Co}(\mathrm{ppm})$ & 5414 & 6802 & 6985 & 5876 \\
\hline $\mathrm{V}$ & 636 & 675 & 815 & 696 \\
\hline $\mathrm{Cd}$ & 3.86 & 4.58 & 3.74 & 3.11 \\
\hline $\mathrm{Mo}$ & 452 & 562 & 649 & 397 \\
\hline
\end{tabular}

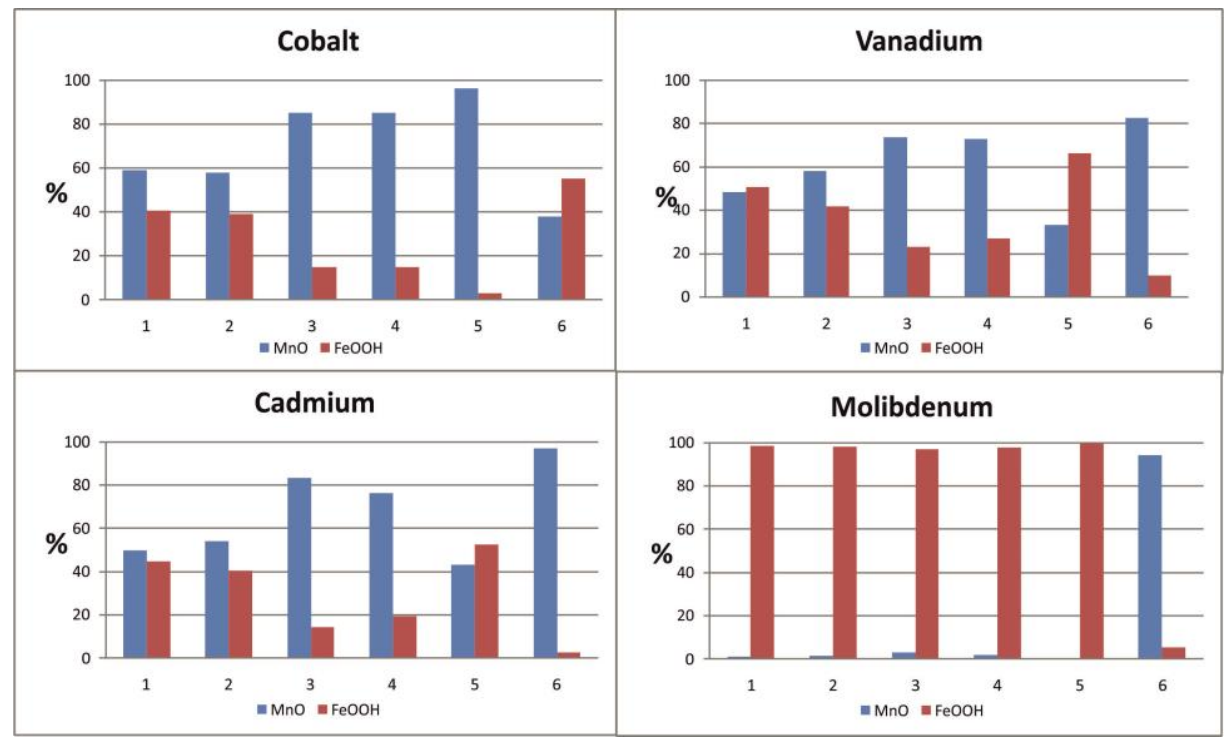

Fig. 2. The percentage of cobalt, vanadium, cadmium and molybdenum in the manganese $(\mathrm{MnO})$ and ferrous $(\mathrm{FeOOH})$ fractions of the Pacific ferromanganese crusts. Hydrogenic: Zubov Guyot, 1 - layer II, 2 - layer III; Govorov Guyot, 3 - layer II, 4 - layer III; Kiribati Area, 5 - layer III (Koschinsky, Hein, 2003). Hydrothermal: 6 - North-Fiji Basin (Koschinsky, Hein, 2003).

A. Koschinsky and J. Hein (2003) after studied different types of FMD showed that V, $\mathrm{Cd}$ and Mo association with manganese phase in hydrothermal crusts and with ferrous fraction in hydrogenetic crusts. Cobalt distribution in CMC mineral phases is opposite (fig. 2 ). Thus, the predominance of these three elements in Mn-oxides, and exist of significant quntaty of $\mathrm{Co}$ in Fe-oxyhydroxides into CMC may reflect hydrotermal sourcse.

About $40 \%$ and $15 \%$ of cobalt are contained into Fe oxyhydroxide of Zubov CMC (1, 2) and Govorov Guyots $(3,4)$, respectively. The dominant oxidation number for Co in seawater is II. $\mathrm{Co}^{\mathrm{II}}$ exists predominantly as $\mathrm{Co}^{2+}$ and ion pairs with $\mathrm{Cl}^{-}\left(\mathrm{CoCl}^{+}\right)$[8]. In high temperature solutions (hydrothermal fluid) the main species of cobalt is $\mathrm{CoCl}_{4}{ }^{2-}$ [9]. Thus, formation of $\mathrm{CMC}$ in typical seawater conditions Co will associations with Mn oxides. Influence of hydrothermal activity lead to increase in concentration negative chlorocomplexes of cobalt and sorption it by negative charge Fe-oxyhydroxides.

Thermodynamically, the predominant species of $\mathrm{V}$ in oxic seawater should be tetrahedral $\mathrm{H}_{2} \mathrm{VO}_{4}^{-}$[10]. It is interesting that absence of experimental data under hydrothermal conditions, the geometry of $\mathrm{V}$-complexes in hydrothermal systems remains unconstrained; extrapolations from room-temperature suggest that tetrahedral vanadate complexes are the most important V-complexes in hydrothermal systems at $300{ }^{\circ} \mathrm{C}[11]$ as 
for seawater at $2-30{ }^{\circ} \mathrm{C}$. At hydrothermal processes $(\mathrm{pH} \leq 3.6)$ there is a direct transition from tetrahedral $\mathrm{H}_{2} \mathrm{VO}_{4}^{-}$to the oxocation $\mathrm{VO}^{2+}[12]$. Thus, decrease $\mathrm{pH}$ has to increase $\mathrm{V}$ oxocations concentration and sorption these complexes by negative charged Mn-oxides.

The Cd speciation in acidic to neutral aqueous chloride solutions at temperatures $\leq 300$ ${ }^{\circ} \mathrm{C}$ is dominated by octahedral $\mathrm{CdCl}_{\mathrm{m}}\left(\mathrm{H}_{2} \mathrm{O}\right)_{6-\mathrm{m}}{ }^{2-\mathrm{m}} \quad(0 \leq \mathrm{m} \leq 1-2)$ and tetrahedral $\mathrm{CdCl}_{\mathrm{n}}\left(\mathrm{H}_{2} \mathrm{O}\right)_{4-\mathrm{n}}{ }^{2-\mathrm{n}}(2 \leq \mathrm{n} \leq 3-4)$ species, with the latter complexes becoming predominant with increasing $\mathrm{T}$ and cloride concentration [13]. Thus, increase cadmium in manganese phase of CMC is, most likely, reflect prevalence Cd octahedral species in hydrothermal fluids.

The predominance of the $\mathrm{V}$ and $\mathrm{Cd}$ in the manganese fraction is characterized for hydrothermal deposits [6] (Fig. 2). High V and Cd in Mn fraction of CMC imply a lower oxidation potential of the fluid during precipitation of the crust. More reduced fluids can reflect higher productivity in surface waters, or circulation of reduced fluids in the seamounts that reflect hydrothermal circulation created during a rejuvenation stage volcanism, or release of pressurized fluids during tectonic events [14]. Consequently, concentration of $\mathrm{V}$ in $\mathrm{Mn}$ phase of $\mathrm{CMC}$ from Govorov and Zubov Guyots may reflect involvement endogenic source for formation bulk chemical composition of the deposits.

The affiliation of molybdenum to the Fe oxyhydrixide is characteristic of all the hydrogenic deposits from various regions of the Pacific (fig. 2). Mo is present in the +VI oxidation state in seawater, predominantly as the highly soluble $\mathrm{MoO}_{4}{ }^{2-}$ species [15], and in hydrothermal fluids it present as negative charge chloride complexes [11]. Experimental data showed that synthetic $\delta-\mathrm{MnO}_{2}$ (Mn phase) is the dominant host phase of Mo [16]. Opposite, sequential leaching experiment of natural hydrogenetic Fe-Mn crust indicated that Mo incorporates with Fe (oxy)hydroxides [6]. Important role of hydrogenetic Fe-Mn deposits formation play bacteria (biomineralization) [17], because seawater is undersaturated by Mn $100-1000$ times [18]. Molybdenum is a biologically great trace element, which is important component in bacteria enzyme complex that included cytochrome oxidase [19]. Mo depletion was observed in vent fluids from different geological settings $[10,20]$. On the other hand, maximum Mo content (up to $2100 \mathrm{ppm}$ ) is observed in arc hydrothermal Mn crusts [21]. Thus, we suppose that concentration Mo in $\mathrm{Fe}$ (oxy)hydroxides of $\mathrm{CMC}$ reflect biomineralization and fluid Mo depletion. And molybdenum scavenging from seawater by Mn-oxides is deal with supersaturated ambient seawater by manganese during hydrothermal activity.

\section{Conclisions}

The study of the elements distribution in mineral phases which marking the hydrothermal source showed that the hydrogenic CMC of guyots are capable record the endogenic sources. This is reflected in an increase in the cobalt content in the ferrous fraction, as well as an increase in the content of vanadium and cadmium in the manganese fraction of the hydrogenic CMC. Yet, little is known about the behavior Mo under hydrogenetic and hydrothermal ferromanganese precipitation and about role of microorganism during growth of crust and nodules. Our results show that Mo host phase is depend on saturation solution by manganese. If Fe-Mn deposits have been formed by chemical precipitation that Mo host phase is Mn-oxides, and if FMD are microbiology genesis Mo host phase is $\mathrm{Fe}$ (oxy)hydroxides.

We thank Dr. M.E. Mel'nikov who supplied samples from Zubov and Govorov Guyots and Dr. O.V. Chudaev and Y. Kharaka for their constructive reviews that greatly improved this article.

The reported study was funded by Russia Science Foundation, according to the research project No. 18-17-00015. 


\section{References}

1. J.R. Hein, K. Mizell, A. Koschinsky, T.A. Conrad, Ore Geol. Rev. 51, 1-14. (2013)

2. T.J. Horner, M. Schönbächler, M. Rehkämper, S.G. Nielsen, H. Williams, A.N. Halliday, Z. Xue, J.R. Hein, Geochem., Geophys., Geosyst. 11, 1-10 (2010)

3. M.E. Mel'nikov, T.E. Sedysheva, V.V. Ivanov, S.P. Pletnev, V.M. Anokhin, Rus. J. of Pac. Geol. 10, 435-442 (2016)

4. F.T. Manheim, Science, 232, 600-608 (1986)

5. A. Koschinsky, P. Halbach, Geochim. Cosmochim. Acta. 59, 5113-5132 (1995)

6. A. Koschinsky, J.R.Hein, Mar. Geol. 198, 331-351 (2003)

7. P.E. Mikhailik, E.V. Mikhailik, N.V. Zarubina, M.G. Blokhin, Rus. Geol. and Geophys. 58, 1530-1540 (2017)

8. R.H Byrne, Geochem. Trans. 3(2), 11-16 (2002)

9. W. Liu, S.J. Borg, D. Testemale, B. Etschmann, J.-L. Hazemann, J. Brugger, Geochim. Cosmochim. 75 (5), 1227-1248 (2011)

10. P. Ho, J.M. Lee, M.I. Heller, P.J. Lam, A.M. Shiller, Marine Chemistry 201, 242-255 (2018)

11. J. Brugger, W. Liu, B. Etschmann, Y. Mei, D.M. Sherman, D. Testemale Chemical Geology, 447, 219-253 (2016)

12. J.P. Gustafsson, Applied Geochemistry, 102, 1-25 (2019)

13. E.F. Bazarkina, G.S. Pokrovski, A. V. Zotov, J.L. Hazemann Chem. Geol., 276, 1-17 (2010)

14. N. Konstantinova, J.R. Hein, A. Gartman, K. Mizell, P. Barrulas, G. Cherkashov, P. Mikhailik, A. Khanchuk, Minerals. 8 (460), 2-20 (2018)

15. F.T. Manheim, Handbook of Geochemistry (Springer-Verlag, K1-K14, 1978)

16. T. Kashiwabara, Y. Takahashi, M. Tanimizu, A. Usui, Geochim. et Cosmochim., 75, 5762-5784 (2011)

17. X.H. Wang, U. Schlobmacher, S.F. Wang, H. C. Schröder, M. Wiens, R. Batle, W. E. G. Müller, Front. Mater. Sci., 6(2), 97-115 (2012)

18. V.S. Savenko, Physico-chemical analysis of the formation of ferromanganese nodules in the ocean (GEOS, 2004, in russian)

19. H.L. Ehrlich, D.K. Newman, Geomicrobiology (Taylor \& Francis Group, 2009)

20. J.H. Trefry, D.B. Butterfield, S. Metz, G.L. Massoth, R.P. Trocine, R.A. Feely, J. Geophys. Res., 99, 4925-4935 (1994)

21. S.A. Moorby, D.S. Cronan, G.P. Glasby, Geochim. et Cosmochim., 48, 433-441 (1984) 